\title{
The Socio-Economic Effect of Early Marriage in North Western Nigeria
}

\author{
Gimba Victor Kyari PhD \\ Department of Economics Kaduna State University, Kaduna \\ Email: gimba1974@yahoo.com
}

Joseph Ayodele

Department of Mass Communication Kaduna State University, Kaduna

Email: tinayo01@yahoo.com

\section{Doi:10.5901/mjss.2014.v5n14p582}

\section{Abstract}

\begin{abstract}
The paper examines the socio-economic effect of early marriage in north western Nigeria using Zaria local government as a case study. Early marriage has been a common practice among many ethnic groups in the world. However, marriage is regarded as a moment of celebration and a milestone in adult life. Sadly, the practice of early marriage gives no such cause for celebration when it is not done properly. In this paper the researcher used primary data from the questionnaires administered. Chi-square statistical technique was used for the analysis and the results show clear that there is evidence "early marriage has a negative effect on girl-child education". Based on this finding the following recommendations are proffered to lessen the rate of early marriage of girl-child as it goes with a negative effect on their education development and consequently, a setback for the growth and the development of Nigerian economy. Promoting education of a girl-child, Educating girls seems to be the ideal solutions to tame the early marriage of the girl-child. Government and NGOS should provide support needed for girls' education including free books, uniform and scholarship. Essentially, put away unwholesome custom and traditional practices that are harmful to girl-child development.
\end{abstract}

Keywords: Girl-Child, VVF, MDGs, HIVIAIDS, Chi-Square

\section{Introduction}

In the pre-independence era when formal education was first introduced in Northern Nigeria, the government through the Native Authority (NA) (which transformed to Local Government Authority) had to force parents to send the girl-child to enroll in formal schools. The NA fully funded the education of these girls who were conscripted to various schools often located outside their province. However, the socio-cultural and religious practices that evolved later in Northern states, particularly the North East and North West changed with the highest number of girl-child not enrolled in school and those who drop out to get married. The majority of these girls never return to school to complete their education, learn a trade, or acquire vocational skills that would economically empower and make them self-reliant.

Every society and culture has some basic norms and beliefs that guide the people. In Nigeria for instance, specifically the Northern Nigeria (Hausa - Fulani dominated) allowed early marriage of the girl-child. Erulkar and Bello (2007) argued that the reason for acceptance of early marriages among Northern region is to preserve the value of virginity, fears about marital sexual activity, to reduce promiscuity of the girl-child, and other socio-cultural and religious norms. However, due to the ignorance and selfish nature, more often than not they forget the effect it has on the girl- child as well as their community development. It is worrisome that the girl- child has no power to resist the offer. The effect of early marriage on the girl-child that affects her wellbeing and that of the society include education, lack of economic empowerment and lack of knowledge on reproductive health services which will enable them take informed decisions, enhance their ability to leverage resources and participate in community decision making.

The factors usually put forward as reasons for the early marriage of girl-child are poverty, unwanted pregnancy, parental pressure, peer pressure and developmental stage among others. More so, it has a negative trend on the girlchild which include emotional and mental distress, intolerance, school drop-out, Vesico Vaginal Fistula (VVF) disease, early widowhood, frustration and hatred for the man as observed by Bala, 2003.

This practice is against the United Nations Children Education Fund (UNICEF) recommendations on the rights of the children which include right to free and full consent to a marriage as recognized in the 1948 Universal Declaration of 
Human Rights (UDHR), education, empowerment, health determination. Most societies like Nigeria has domesticated these international agreements and enacted Acts that will further enhance the rights of the children. But implementing the Acts in most Northern states has been controversial as some of the states are also being guided by Islamic laws that have a soft landing on early marriage by considering age as not a very significant factor in marriage.

In 1990, the World Conference on Education for All (EFA) identified improving access to quality education for girls and women as "the most urgent priority". More than one hundred countries re-affirmed this at the April 2000 Dakar World Education Forum; 'ensuring that by 2015 all children, with special emphasis on girls, have access to and complete a primary education of good quality." At this meeting (the Dakar World Education Forum), the United Nations SecretaryGeneral, Kofi Annan, launched the UN Girls' Education Initiative (UNGEI). In an unprecedented step, 13 UN entities, led by UNICEF agreed to work together on this 10-year initiative to help governments meet their commitments to ensure a quality education for all girls globally. It was generally agreed that:

\begin{abstract}
"discrimination against the girl-child and the violation of the rights of the girl-child, which often result in less access for girls to education, nutrition and physical and mental health care and in girls enjoying fewer of the rights, opportunities and benefits of childhood and adolescence than boys and often being subjected to various forms of cultural, social, sexual and economic exploitation and to violence and harmful practices, such as female infanticide, rape, incest, early marriage, forced marriage, prenatal sex selection and female genital mutilation."
\end{abstract}

The resolution reiterates the commitments to undertake legal reforms to ensure the rights of girls, to provide for equal access to basic social services (such as education, nutrition, vaccination, and health care, including sexual and reproductive health care), to enact and enforce legislation against all forms of violence and exploitation and to protect girls affected by armed conflict.

Early marriage has been a common practice among many ethnic groups in the world including Nigeria. However, it has contributed to series of negative consequences both for young girls and the society in which they live. It is a violation of human rights in general and of girl's rights in particular. For both girls and boys, early marriage has profound physical, intellectual, psychological and emotional impacts, cutting off educational and employment opportunities and chances of personal growth. In Northern Nigeria where the practice is prevalent, the impact is more on girls as many of them marry early in their large numbers and with more intensity.

Besides having a negative impact on girls themselves, the practice of early marriage also has negative consequences on their children, families, and society as a whole (Adedokun, et. al., (2012). They argued that it is not only girls that pay for early marriage but also the society as a whole. Population pressure, health care costs and lost opportunities of human development (because of lack of education) are just a few of the growing burdens that society shoulders because of teenage pregnancies. Early marriage also undermines international efforts to fight against poverty in developing countries. This points to the fact that the widespread practice of child marriage makes it increasingly difficult for families to escape poverty in the developing countries like Nigeria, thereby undermining critical efforts by the three tiers of government to address education challenges, fight poverty, HIVIAIDS and other development challenges.

The factors usually put forward as reasons for the early marriage of girl child are poverty, unwanted pregnancy, parental pressure, peer pressure and developmental stage among others. Moreso, it has a negative trend on the girl child which include emotional and mental distress, intolerance, school drop-out, Vesico Vaginal Fistula (VVF) disease, early widowhood, frustration and hatred for the man as observed by (Bala, 2003).

Marriage is regarded as a moment of celebration and a milestone in adult life. Sadly, the practice of early marriage gives no such cause for celebration. All too often, the imposition of a marriage partner upon a child means that a girl or boy's childhood is cut short and their fundamental rights are compromised (UNICEF, 2005). Young girls are robbed of their youth and required to take on roles for which they are not psychologically or physically prepared. Many have no choice about the timing of marriage or their partner. Some are coerced into marriage, while others are too young to make an informed decision. Premature marriage deprives them of the opportunity for personal development as well as their rights to full reproductive health and wellbeing, education, and participation in civic life. Against this background, a paper of this nature is necessary in other to create awareness of the importance of girl-child education in Nigeria and in the Northern region in particular if it could answer questions such;

i. What are the effects of early marriage on girl-child education in Nigerian?

ii. What are the consequences of early marriage of girl-child in Nigerian?

iii. What are the possible ways to address the challenge of early marriage of girl - child in Nigeria? 


\section{Literature Review and Theoretical Framework}

\subsection{Conceptual and Theoretical Issues}

The term "early marriage" is used to refer to both formal marriages and informal unions in which a girl lives with a partner as if married before age of 18 (UNICEF 2005). Similarly, UNIFPA (2006) defines early marriage and child marriage, any marriage carried out below the age of 18 years, before the girl is physically, physiologically, and psychologically ready to shoulder the responsibilities of marriage and childbearing. Child marriage, on the other hand, involves either one or both spouses being children and may take place with or without formal registration, and under civil, religious or customary laws.

Ango (1991) defined early marriage as either marriage of an adolescent girl/boy or marriage of an adolescent girl to a matured man or vice-versa and this happens at puberty when the individual is getting matured. The marital age according to Molokwu (2000) is above the age of 18 years, when the individual is physically, socially, academically and emotionally matured to cope with the challenges of marriage. The Nigerian review draft decree put the marriageable age of the girl-child at 18 years. Also, the UNICEF (2001) on the rights of the child recommends that children should not be separated from their parents before 18 years unless it is considered necessary.

The Convention on the Elimination of All Forms of Discrimination Against Women (CEDAW), the most comprehensive international bill of rights for women, states that any betrothal or marriage of a child should not have any legal status. The Committee that monitors this convention states further in General Recommendation 21 (Article 16(2)) that the minimum age for marriage for both male and female should be 18 years, the age when "they have attained full maturity and capacity to act". Most early marriages are arranged and based on the consent of parents and often fail to ensure the best interests of the girl child. Early marriages often include some elements of force, (Otoo-Oyortey and Pobi 2003).

The lack of an overarching definition of early marriage in international conventions has generated some debate. Some scholars and activists, argued that instead of looking for a universal age at which girls and boys should not marry, the focus should be put instead on eliminating the unwanted effects of early marriage (Women's human rights resources, http://www.lawilb.utoronto.ca/Diana/index.htm). Some suggested that a universal age of marriage is not appropriate, in part because societies have different understanding of what it means to be a child as well as different socio-economic and cultural realities. Bunting (1999) proposes that governments should be allowed to set the age of marriage below 18 years of age, but that the onus is on them to demonstrate that this lower age does not result in any discrimination or adverse consequences for women.

Child marriage is the practice of marrying a young girl (generally defined as below the age of eighteen) to an adult. In most cases, it is always a young girl married to a matured man. It is a situation where female adolescents and teenagers are married to adult husbands. In these instances, sometimes, the men can be twice their ages and these females become child brides.

Adedokun, et. al., (2012) observed that child marriages are often arranged in two distinct ways, within a context of force and coercion, either by parents or other persons in positions of authority in the family arranging their young daughter's marriage to an adult, often a much older man or arranging the future marriage of two children. It is not uncommon to find girls of $7-14$ years already married off with the girls sent off to live with the families of the husbands. Generally, prospective husbands are selected based on social, religious and monetary factors and age is not considered an important factor, as husbands are on the average 12 years older than the child brides in monogamous unions and up to 15-20 years older in polygynous unions (Population Council, 2005) and in isolated cases, may be several decades older.

Child marriage equals early marriage. This inevitably denies children of school age their right to the education for their personal development, preparation for adulthood and effective contribution to the future well-being of their family and society. The interaction between the number of years of a girl's schooling and the postponement of marriage is firmly established by demographic and fertility studies. On the average, women with seven or more years of education marry four years later and have 2.2 percent fewer children than those with no education. Meanwhile, it has been rightly observed that there is better tool for effective development than education of girls. It lowers infant mortality, promotes health, improves nutrition, raises economic productivity, enhances political participation and prepares the ground for educating the next generation.

The clarion call for the liberation of the girl- child from the shackles of early marriage and her attendant relegation to a vulnerable position has continued to be resisted with traditional customs and religious beliefs, despite the United Nations declarations (UNICEF, 2001) on the fundamental human rights of the girl-child. Child marriage is regarded as a 
global problem that undermines global development efforts towards achieving more educated, healthier and stable populations as it often involves discontinuance of education, early severance of family ties, separation of the child-bride from her peers, domestic violence, early sexual activity and child bearing associated with health complications. Significantly, the practice has received universal condemnation and has been identified as contributing greatly to the slow pace of achieving the Millennium Development Goals (MDGs) (eradicating extreme poverty and hunger, achieving universal primarily education, promoting gender equality and empowering women, reducing child mortality, improving maternal health and combating HIVIAIDS, cervical cancer, sexually transmitted diseases, VVF, malaria and other diseases) in many countries.

Judging from the array of socio-medical consequences of early marriage, it is only logical for countries to legislate against child marriages. Nigeria followed suit by enacting 'Child Rights Act 2005' which amongst others out rightly prohibits child marriages. The paramount issue however, is the effective implementation of this law.

\subsection{Empirical Review}

Early marriage has been the subject of a growing number of studies, research projects and intervention programs in Africa. Some part of Africa and Northern Nigerian women marry at a much earlier age than other part of the world, leading to early pregnancies. Surveys carried out in some Sahelian countries by Locoh (2000) had alarming examples. In Niger, for example, according to the 1992 Health and Demographic Survey (HDS), 47 percent of women aged between 20 and 24 were married before the age of 15 , and 87 percent before the age of 18 . A total of 53 percent had also had a child before the age of 18 .

Lefebvre, et. al., (2004) observed that more women are now marrying at later ages, in many regions, early marriage remains the norm. Overall, 20-50 percent of women in developing countries are married by the age of 18, with the highest percentages in Sub-Saharan Africa and part of South Asia.

Forward (2008) observed that child marriage is predominantly practiced in the rural and poor communities where young girls are regarded as economic burden and quickly married off to alleviate household expenses. Oftentimes, in these communities, educational and economic opportunities available to girls are few and they are often married off quickly to protect them and the economic wellbeing of the family. The continuing economic hardship in many developing countries is encouraging a rise in early and child-marriage, even among populations that do not normally practice it, as child marriage is often regarded as a family-building strategy, an economic strategy and the resulting transaction important for the financial and social survival of the child and her family. Where poverty is acute, also, parents may regard young girls as economic burden and their marriage to much older rich men becomes very attractive and beneficial to the girl and her family. He concluded that a daughter may be treated as a commodity that the family has to be traded and sometimes girls are used as currency to settle debts or stabilize relationships between families.

Lloyd (2005) asserts that in many parts of Africa, Nigeria inclusive, the bride price or wealth, paid in exchange for the bride's labour and fertility is an important resource for greater wealth and survival of the family and therefore may induce early arrangements of marriage by parents. Existing notions of morality and honour are important influences on decisions of parents to marry off daughters very early to ensure that a girl's virginity is preserved at marriage, as culturally expected in order to purchase the highly valued virtue for the girl and honour for her family. In the absence of viable options, early marriage is seen as a way of protecting girls from unwanted pregnancies. When such marriages are to older men, they are also considered as necessary guardians against possible immoral and inappropriate behavior on the part of the young wives.

Giyan (2009) argued that some religious practices, such as Islam encourage early marriage and parents imbibe this for fear of their daughters being pregnant out of wedlock and the only available option could be marriage at an early age. Early marriage has been defended in Nigeria as clearly permissible by the Islamic religion, but with the cautionary measure that such marriages can only be consummated when the bride is mature enough. He concluded that most times these decisions are often made without the consent of the child and with no recourse to the consequences of the actions.

UNICEF (2010) observed that the marriage of young person's less than 18 years is still widely practiced in many parts of the world but remains prevalent in countries of Africa, Latin America and the Caribbean as well as Southern Asia and predominantly affects girls. It was estimated that, if nothing changes, a 100 million young girls aged 15 years or less will be married within the present decade. Regional estimates of its occurrence for girls include 48 percent in Southern Asia, 42 percent in Africa and 29 percent in Latin America and the Caribbean with wide differentials across the countries. In the West African sub-region, the proportions of girls affected vary from 28 to 43 percent (Ghana, Togo, Cote d'Ivoire, Senegal, Benin, and Nigeria) to 60 to 80 percent (Burkina Faso, Guinea, Mali, Chad and Niger).

Abdallah (2011) in a study observed that in Nigeria, the practice of child marriage is deeply entrenched in tradition, 
culture and religion and the country has one of the highest rates of child marriage in the world, with estimated 42 percent of girls married before 18 years; and while this is found among many ethnic groups across the country, its predominance is clearly in the northern part of the country. While nationwide, 20 percent of girls are married by age 15, and 40 percent are married by age 18, child marriage is extremely prevalent in some regions such as among the predominantly Muslim Hausa-Fulani of the Northwest and North-East (of which Zaria is a part) where 48 percent of girls are married by age 15 , and 78 percent are married by age 18. While average age at first marriage is 17 years nationwide, average age of marriage for girls is just over 11 years in Kebbi State and about 15 years in most other parts of northern Nigeria. Among the Yorubas, made up of a mixture of Christians and Muslims in the South-West, child-marriages are no longer arranged and for the Igbo in the South-East that are predominantly Christians, the practice has declined considerably and restricted to few communities and situations where pregnant teenagers are forcefully married off, to prevent family shame or restore honour.

Bayisenga (2012) examined the issue of early marriage in sub-Saharan Africa. It sheds light specifically on reason behind its perpetuation, its harmful consequences which include barrier to education, enjoyment of girl's human rights and how it further threatened the development of countries. He observed that early marriage is due to various factors including among others, the search for economic survival, protection of young girls, peer group and family pressure, controlling female behavior and sexuality, wars and civil conflicts and socio-cultural and religious values. It is a violation of girl's human rights as it deprives her from freedom, opportunity for personal development, and other rights. It also a developmental challenge for population pressure, health care costs and lost opportunities of human development. It is barrier to girl's education as young girls drop out from school to get married which impacts negatively on the community as whole and on the wellbeing of future generation. This practice stands in direct conflict with the objectives of the Millennium Development Goals (MDGs); such as the promotion of basic education, fight against poverty, the prevention of HIVIAIDS and reduction maternal mortality rate.

Adedokun, et. al., (2012) examined the maternal health implications of early marriage on young mothers in Gombe, using data obtained from 200 young mothers aged 15-24 years. The study revealed that more than 60 percent had only primary education, 50 percent had been married for between 5-9 years and more than 70 percent had experienced complications before or after childbirth. Age at first marriage, current age, level of education and household decisionmaking influence maternal health risks in the study area. Entitlements and freedoms that are highly relevant to reduction of maternal mortality, provided by international treaties are inaccessible to young women in the study area.

Nwokolo (2012) investigated the capacity building strategies for counseling against early marriage of the Girl-child in Ogidi Education zone of Anambra state. Three research questions were used and descriptive survey design was adopted. The population for the study is all the parents who are members of the parents' teachers' association of all the schools in Ogidi education zone and all the eleven counselors in the chosen zone. A sample of 660 respondents was chosen through random sampling and all the 11 counselors were chosen because the population size is small. On the whole 671 respondents were used for the study. Instrument used was questionnaire and mean rating was used as the statistical tool. The results showed that all but one of the items are the capacity building strategies as agreed by the respondents. This implies that unless the parents work together with the counselors, counseling might not contribute much in the fight against early marriage of the Girl-child.

In 2009 Nigerian Demographic and Health Survey (NDHS), it was reported that in 26.5 percent couples, there is an age difference of 15 or more years between husband and wife. Equally, it showed the median age of marriage in the South West and South East was 20.2 years whilst those of the North West was 14.6 years and slightly higher in the North East with 15.0 years. It concluded that there was a large zonal variation in the mean age of marriage with females in the North marrying on an average of about five years earlier than those in the South (NPC, 2010).

A study based on the 2003 NDHS revealed that the timing of marriage varies considerably by region and area of residence 5. The median age at marriage is lowest among girls in North West and North East regions, at 15.8 and 16.8 years respectively. Rural girls were more likely to marry early compared with urban girls; for example, in the North West, 29 percent of urban girls married by age 15 compared with 65 percent of their rural counterparts who are married at the same age. The timing of marriage among girls in the southern regions is later. Another significant factor from the 2003 survey was that rural girls were more likely to get married earlier than urban girls. It is quite glaring that there is higher incidence of child marriage in Northern Nigeria.

Erulkar and Bello (2007) conducted a multi country research which included Nigeria. The findings showed that the modern contraceptive usage rate among married child brides from 15-19 years old in Nigeria is 0.6 percent. This percentage is very negligible; such child brides in most cases cannot determine the period of pregnancy and are prone to early pregnancy. With this, they are susceptible to the increased risk of dying, increased risk of premature labour, low birth rate and higher chances that the newborn babies will not live. There are also the serious medical complications of 
Vesico-Vagina Fistula (VVF) and Rectum Vagina Fistula (RVF). It is pathetic that girls with such medical conditions are considered unclean and ostracized by society. They discovered that in Nigeria, this condition affects 150,000 women. Out of this, a whole lot of 80-90 percent of wives with VVF are divorced by their husbands. They also observed that most of them lack basic education.

From the review of previous studies, it is evidence that a number of factors are responsible for early marriage of girl child marriage in various countries including Nigeria. The consequences of such action has contributed immensely to the non-achievement of gender equality, absolute poverty and hunger reduction, universal basic education, and improved health and reduction in maternal and infant death, HIVIAIDS, etc. in Africa and other third world countries.

\section{Research Methodology}

To ensure proper collection and analysis of data in this paper, the researcher resolved to collect both primary and secondary data. This approach aimed at making sure that all the relevant materials or information required for the study were acquired and utilized. The primary data were acquired through the administration of questionnaire in Zaria. The questionnaire designed is in two parts: the first part is a classification section that requires such details of the respondent sex, age occupation, qualification, etc. The second part possesses the questions relating to the subject matter of the investigation. The responses for this second part form the basis of our data presentation and analysis. The questionnaire designed contained both open and closed questions. This implies that the questionnaire provided the respondent with the opportunity to have the freedom to decide the aspect, detail and length of the answer and some questions designed to keep the respondent to a reasonable length. The basis of this is to permit easier tabulation, interpretation by the researcher.

The population of this study comprised all the residents of Zaria. A total of one hundred and twenty five (115) questionnaires were distributed to respondents out of which one hundred (100) were duly completed and returned. Therefore, the sample size of the study is one hundred (100).

The sampling procedure employed in this study is the simple random and stratified sampling methods.. The choice of this technique is informed by the fact that the selection of any of the element of the population of study must be done without bias. The stratified sampling reflects the ease with which different strata of the people are included in the sample survey for properly representation of the survey population. The various strata are men and women, young and old or different religion.

The questionnaires were administered directed to the respondents who are residing at Zaria. The questionnaires were retrieved through direct collection from respondents.

The basis analyses used in this study are the conventional instruments that are frequently employed for the statistical analysis and measurement.

Two hypotheses were formulated base on the research question from section one and a chi-square statistic was used for the analysis.

\section{Results and Discussion of Findings}

As earlier stated in section three, the hypotheses formulated for the purpose of this research work would be tested using the statistical technique of chi-square $\left(x^{2}\right)$. For the sake of this study three separates hypotheses were tested;

\subsection{Hypothesis 1}

Hypothesis one states that there is no significant relationship between early marriage and girl child education. Therefore, based in the result in Table 1 it clear that the null hypothesis of no significant relationship between early marriage and girl-child education is rejected as $5 \%$ level of significant. The hypothesis is rejected in the case of chi-square, likelihood ratio and reject by linear. The null hypothesis therefore, is rejected in strong terms and the alternative hypothesis accept that there exist a significant relationship between early marriage and girl-child education. This implies that if children are given in marriage it would certainly affect their level of education. This result tallies with UNICEF report on conditional cash transfer. (CCT) of 2013. 
Table 1: Relationship Between Girl-Child and Education

\begin{tabular}{l|c|c|c}
\hline & Value & Df & Asymp. Sig (2-sided) \\
\hline Pearson Chi-Square & $22.004^{a}$ & 6 & .001 \\
Likelihood Ratio & 24.350 & 6 & .000 \\
Linear-by-linear association & 4.217 & 1 & .040 \\
N of Valid Cases & 300 & 1 & \\
\hline
\end{tabular}

\section{Source: SPSS Out}

\subsection{Hypothesis 2}

Hypothesis 2 state that there is no consequence of early marriage on girl child. Therefore, based on the result in Table 2 it clear that the null hypothesis of no consequence of early marriage on girl child is rejected as $5 \%$ level of significant. As in the of hypothesis 1, the second hypothesis was rejected in the three cases of chi-square, likelihood ratio and by linear. The null hypothesis therefore, is rejected in strong terms and the alternative hypothesis accept that there exist a consequence of early marriage on girl child. This implies when a girl-child is given out in marriage she might face a major consequence of school dropout, health related problems and poverty. This results is in line with report of a survey conducted by population media center (PMC) 2010. The report shows that early marriage is the cause of fistula, illiteracy and poverty among women in northern Nigeria.

Table 2: Consequence of Early Marriage

\begin{tabular}{l|c|c|c}
\hline & Value & df & Asymp.Sig (2-sided) \\
\hline Pearson Chi-Square & 65.624 a & 6 & .000 \\
Likelihood Ratio & 69.801 & 6 & .000 \\
Linear-by-linear association & 2.824 & 1 & .093 \\
N of Valid Cases & 300 & & \\
\hline
\end{tabular}

\section{Source: SPSS Out}

This paper examines the effects of early marriage on girl child education using Zaria local government area as case study. The main instrument use in the paper was questionnaire. While chi-square is the statistical method employed to analyze survey data. Two hypotheses were tested and the results show that (i) early marriage of the girl child significantly affect the education of the girl child and (ii) early marriage of the gild child has significant consequences on the girl child. These results have an overall impact on the economy development of youths and the nation at large.

The paper shows that child marriage is an accepted cultural practice in many societies including North west. It is still widely sanctioned, even though it is a violation of the human rights of young girls due to various motives. Early marriage can violate the rights of girls and boys, but it effect upon girls is far larger numbers and with more intensity. More emphasis has been given to girls as the experience for boys is, less likely to be exploitative or physically harmful as it is for girls. The imposition of a marriage partner on children or adolescents who are in no way ready for married life, and whose marriage will deprive them of freedom, opportunity for personal development, and other rights including health and well-being, education, and participation in civic life, nullifies the meaning of the Convention on the Rights of the Child's core protections for those concerned.

\section{Conclusion}

Early marriage still thrives in spite of various conventions against the practice. Although reasons often adduced in favour of the practice may appear attractive on face value, the physical health and psychological consequences of early marriage can constitute a huge price. Education of the girl-child must take pre-eminent position in order to stem the tide of early marriage and its consequences.

Numerous severe consequences result from the practice of early marriage. Early marriage is intrinsically linked to low levels of education, high levels of violence and abuse, social isolation, severe health risks and harmful power dynamics and results in increased gender inequality and vulnerability to poverty for girls, young women, families and the society as a whole. This practice also threatens the international development effort to fight against poverty and related 
challenges in developing countries.

To trickle this challenging phenomenon, a joint effort to formulate and implement policies and strategies is needed; Actions to fulfill or restore the rights of those already married should go hand in hand with preventive actions to insure that all of the interventions are available to married, as well as to unmarried girls.

\section{Recommendations}

From the findings of this study the following recommendations are proffered to enhanced organizational performance:

Providing economic opportunities to girl child. Poverty is one of the major factors underpinning early marriage.

Efforts to improve the, access of young married and non-married girls to economic resources should focus on expanding employment and entrepreneurial opportunities.

Promoting education of girl child. Educating girls seems to be the ideal solution to tame early marriage of the girl child. Government and NGOs should provide support needed for girls' education including free books, uniforms, scholarship and so on.

Using mass media to increase the awareness of the whole community about the consequences of early marriage on girls themselves, their family and on the community as a whole. This will lead to the empowerment of girl child into skills for self-confidence, assertiveness, speaking out, decision- making and negotiation.

\section{References}

Abdallah, B. A. (201l): Girl Child Marriage and Women Development in Nigeria: Contemporary Issues", Journal of Development and Psychology 14(9): pp.248-259.

Action Health Incorporated (2012): "Insights into Early Marriage and Girls' Education in Northern Nigeria", AHI Lagos, Sponsored by David and Lucile Packard Foundation,

Adedokun, G. N., Tochukwu, H. E. and Adedeji, 0. 0. (2012): "Early Childhood Marriage and Early Pregnancy as a Risk to Safe Motherhood", A Report on the Regional Conference on Traditional Practices Affecting the Health of Women and Children in Africa, 19-20 Nov. ICA

Akpan, T. P. (2003): "Early Marriage and Education", Newsletter, 7, EENET, mnt.,

Ango, R. G.(1991): "The. Impact of Girls' Education on Early Marriage", Independent Evaluation Report: CAMIFED and CAMA Programmes Zimbabwe, September.

Bala, B. T. (2003): Teen pregnancy: A Global Tragedy New York: Watchtower Bible and Tract Society Inc. October 8.

Barnes, G., Fores, Y. U and Temius, D. (1998): "Trends in timing of first marriage among men and women in the developing world. In The changing transitions to adulthood in developing countries: Selected studies (pp. 118-171). Washington, D.C.: National Academies Press.

Bayisenge, J. (2012):"'Early Marriage as a Barrier to Girl's Education: A Developmental Challenge in Africa", Journal of Social Psychology 12(6): pp. 23-48.

Bhat, A., Sen, A., \& Pradhan, U. (Eds.). (2005): Child marriages and the law in India. New Delhi: Human Rights Law Network.

Bunting, A. (1999): "Particularity of Rights, Diversity of Contexts: Women, International Human Rights and the Case of Early Marriage, Doctoral Thesis, University of Toronto, Faculty of Law.

Catholic World Relief and USAID (December 2008): "Education Programming for Orphans and Vulnerable Children Affected by or Vulnerable to HIV: Moving beyond school fees and uniforms", Final Report.

Clark, S. (2006): Protecting young women from HIVIAIDS: The case against child and adolescent marriage. International Family Planning Perspectives, 32(2), 79-88.

DFID (2005): "Maternal Literacy and Child's Academic Achievement", Insights 6: pp. 1-3. (UR: Treffgame, T.N).

Effah, N. (1996): "Child marriage in Rwanda Refugee Camps". Africa; Journal of the International African Institute: vol.68, No 2 Edinburg University Press.

Erulkar, A. and Bello G. (2004): The Experience, of Adolescence in Rural Amhara Region Ethiopia. UNFPA, UNICEF, and 'Population Council. Population Council: New York.

Forum on Marriage and the Rights of Women and Girls (2001): Early Marriage and Poverty Exploring Links for Policy and Programme Development London: Forward.

Forum for Women Cooperation and Wealth (2001): "Women's Empowerment: Effect of Participation in Self-help Groups", (FWCW) Indian Institute of Management, Bangalore.

Garima, J.,B. Vikram, and S. K. Singh, J. Piyush, (2012): "Early Marriage of Girls As a Barrier to Their Education", International Journal of Advanced Engineering Technology Vol.11, Issue III, July-September: pp. 193-198

Giyan, H. A. (2009): Women and Education: Equity and Equality. Berkley: McButcheon.

Guday, E. (2012), "Early Marriage and Its Effects on Girls' Education in Rural Ethiopia: The Case of Mecha Woreda in West Gojjam, North-Western Ethiopia", Dissertation Submitted for Doctorate/Doctoral Grade in Ethnology (Social and Cultural Anthropology) to the Faculty of Social Sciences, Georg-August University of Goettingen, (Unpublished) 
Gupta, G. R. (2005), Forum on child marriage in developing countries. Forum presented at U.S. Department of State, "September 14. Heinonen, Paula (2002). "Early, Forced Marriage and Abduction (efma) and their links to Custom/Tradition, FGM, Poverty, and HIVIAIDS". Oxford University: Center for Cross-Cultural Research on Women www.fourliteracies. org/Word\%2Odocuments/EFMA\%2OSYNOPSIS.doc

Hussain, R. and A.H. Bittles (1999): "Consanguineous marriage and differentials in age at marriage, contraceptive use, and fertility in Pakistan." Journal of Biosocial Science 3 1(1): 121-38.

International Center for Research on Women (2008): "Too Young to Wed, Child Marriage in the own Words", ICRW, Washington, DC.

Janvier, R. and Julius, K. (2013): "Exploring educational and socio-economic effects of early marriage: A grounded theory study of the cultural practice of semi-nomadic pastoralist cultures in rural Tanzania", Early Marriage Tragedy in Maasai Society Foundation

Keiper, T. A. and Rugira, J. (2011): "Resolving Inner Cultural Conflicts Toward

Education: A grounded theory study of the vulnerable from semi- nomadic pastoralist cultures in rural Tanzania", International Journal of Educational Development, 22(5): 527-547.

Khabir, J. (2005), "Marriage Patterns in Rural India: Influence of Socio-cultural Context", In The changing transitions to adulthood in developing countries: Selected studies (pp. 172-199). Washington, D.C.: National Academies Press.

Le Fevre, J., Quiroga, R. and Murphy, E. (2004): Future Options Foreclosed: Girls Who Marry Early. Drawn in part from the UNICEF report, Early Marriage, Child Spouses (UNICEF, 2001).

Lewis, I. (2009), "Early marriage and education, Newsletter No_ 7 - Early marriage and education - EENET.rnht

Locoh, T. (2008), "Early marriage and motherhood in sub-Saharan Africa - brief article 'African environment - woman and African: cutting both ways' editions, http://findartic1es.com/p/articles/rni_m2872/is_i_26/ai_62793 785/

Lloyd, C.B. and Mensch, B.S. (2006), "Marriage and Chilabirth as factors in School Exit: An Analysis of DHS Data from sub-saharam Africa", Population Council 219,

Malhotra, G. A. and Mather, M. (1997), "Do Schooling and Work Empower Women in Developing Countries?" Gender and Domestic Decisions in Sri Lanka. Sociological forum, Vol. 12, No.4.

Mathur, S. and A. Maihotra (2003), "Too Young to Wed: The Lives, Rights and Health of Young Married Girls", ICRW, International Center for Research on Women Website: http://www.icrw.org : Washington D.C.

Molokwu, B. (2000), "Gender assessment: Issues and Perspectives", Rwanda ISP Kigali, Rwanda

Otoo-Oyortey, N. and Sonita Pobi. (2003), "Early Marriage and Poverty: Exploring links for policy and program development. The Forum on Marriage and the Rights of Women and Girls in collaboration with the International Planned Parenthood Federation.

NPC (2010), National Demographic and Health Survey 2009/10", National Population Commission, Abuja.

NPC (2009), National Demographic and Health Survey 2008/09", National Population Commission, Abuja.

Nour (2006), "Save the girl child", Journal ofPsychologyl2(9): pp. 167-184. Nwokolo, C. (2012), "Counselling Against Early Marriage of the Girl-Child in Anambra State",

Okereke, C. I., Uwakwe, J. 0., and Nwamuo, P. (2013), "Education an Antidote Against Early Marriage for the Girl-Child", Journal of Educational and Social Research Vol. 3 (5), August: pp. 73-2.

Population Council. (2008): Child marriage in Francophone West Africa. N.Y USA.

Sachs, G. (2005), "Early marriage and HIVIAIDS: Risk factors among young women in India", Economic and Political Weekly, 42(14): pp. 1291- 1297. http://www.popcounci1.org/projects/abstracts/EPW_42 14 .htrnl

Singh S. and Samara R. (1996), "Early marriage among women in developing countries" in International Family Planning perspectives, vol.22, No 4 pp 148-157+175, Guttmacher Institute.

UN (2007), "The millennium Development Goals, Report 2007", United Nations, New York. Retrieved 12, August, 2013 http://www.un.org/mi1lenniumgoals/pdf/mdg2007.pdf

UNICEF (2010): "Child Marriage Advocacy Program: Fact Sheet on Child Marriage and Early Union

UNICEF (2005): Early Marriage: A Harmful Traditional Practice. UNICEF: New York, USA. www.unicef.org/childmarriage

UNICEF (2004), "Child Marriage Advocacy Program: Fact Sheet on Child Marriage and Early Union

UNICEF (2003): Early Marriage: Whose Right to Choose? Mission Statement of the Forum on Marriage and the Rights of Women and Girls.UK.

UNICEF (2001): "Early Marriage: Child Spouses", Accessed on 8th August, 2013 www.unicef.org/childmarriage,

UNICEF (1994): "Child Marriage Advocacy Program: Fact Sheet on Child Marriage and Early Union

UNFPA. (2006): "In ending child marriage, A guide for global policy action International Planned Parenthood Federation and the Forum on Marriage and the Rights of Women and Girls. U.K.

UNFPA. (2004): "Child Marriage Advocacy Program: Fact Sheet on Child Marriage and Early Union

Uvuza J. and Brown J. (2006): "Woman's Land Rights in Rwanda: How can they be protected and strengthened as the Land Law is implemented? Kigali, Rwanda.

WHO (2009): Women and Development: Strategies. World Health Organization, Geneva.

WHO (2006): The Endangered Sex: Neglect of Female Chi1dren Ithaca: Cornell University Press (World Health Organization).

Women International Network (2009): Women, Family, and Child Care: A World in Transition. Cambridge University Press.

Zozulya, T. H. (2011): "Gender in Education and Development". In: Journal of International Cooperation in Education, 1(1):43-62). Japan Hiroshima University: Center for the Study of International Cooperation in Education. www.home.hiroshimau.ac.ip/cice/yokozeki1-1.pdf 


\section{Appendix}

\section{Research questionnaire}

\section{Dear respondents,}

This questionnaire on the subject "The Impact of Early Marriage on Girl - Child Education in Nigeria, Case Study of Zaria LGA", has been designed purposely to collect information for this study.

I therefore, solicit for your assistance and objective response to the survey questions for the success of this study. Please tick (' 1 ) the appropriate box provided for the answers.

Thank you for your anticipated cooperation.

\section{Section A: Bio - Data}

1. Age
a. $20-30()$
b. $31-40()$
c. $41-50()$
d. 50andabove ()

2. Sex
a. Male ()
b. Female ( )

3. Marital Status?
a. Married (
) b. Single
)

4. Educational Qualification
a. Quran/School certificate
b. NCE/OND
c. HND/Degree
d. Master's degree and above
e. Any other, please specify

5. Age at Marriage
a. Below 15 Years
b. 16-20 Years
c. 21-30 Years
d. 31 Years and above

6. Occupation
a. Farming
b. Business/Trading
c. Civil servant
d. Unemployed/Student

\section{Section B}

7. Early marriage affect girl child education?
a. Strongly Agree
b. Agree
c. Disagree
d. Strongly Disagree

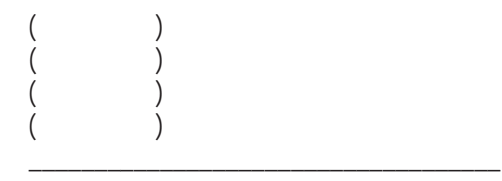

8. Early married has health effect on girl child?
a. Strongly Agree
b. Agree
c. Disagree
d. Strongly Disagree 
9. Early marriage has psychological implication on girl child?
a. Strongly Agree
b. Agree
c. Disagree
d. Strongly Disagree

10. The Child Right Act is not influencing girl child education?
a. Strongly Agree
b. Agree
c. Disagree
d. Strongly disagree

11. The custom, tradition and religion is contributing to early marriage of girl child?
a. Strongly Agree
b. Agree
c. Disagree
d. Strongly disagree

12. The economic situation is contributing to girl child marriage?
a. Strongly Agree
b. Agree
c. Disagree
d. Strongly disagree

13. Girl child marriage has maternal mortality and morbidity effect?
a. Strongly Agree
b. Agree
c. Disagree
d. Strongly disagree

14. Girl child marriage is open to domestic violence and sexual abuse?
a. Strongly Agree
b. Agree
c. Disagree
d. Strongly disagree

15. Girl child marriage hamper her development?
a. Strongly Agree
b. Agree
c. Disagree
d. Strongly disagree

16. The girl child bride does not play a significant role in family decision taking?
a. Strongly Agree
b. Agree
c. Disagree
d. Strongly disagree

17. Do you support girl child marriage in modem day society?
a. a. Yes (
) b. No
)

18. What will you suggest as ways, of addressing girl child marriage 